\title{
Combined use of absolutely quantitated cyclin D1 and Ki67 protein levels to improve prognosis of Luminal-like breast cancer
}

Short title: Prognosis based QDB-based cyclin D1 \& Ki67 protein quantitation

Junmei Hao ${ }^{1 *}$, Wenfeng Zhang ${ }^{2}$, Yan Lv², Jiarui Zou'1, Yunyun Zhang ${ }^{2}$, Jiahong Lv², Shuishan Xie ${ }^{1}$, Cuiping Zhang ${ }^{1}$, Jiandi Zhang ${ }^{2,3} \#$ \& Fangrong Tang ${ }^{2}$

1. Department of Pathology, Yantai Affiliated Hospital of Binzhou Medical University, Yantai, P. R. China

2. Yantai Quanticision Diagnostics, Inc, a division of Quanticision Diagnostics, Inc (US), Yantai, P. P. China

3. Center for Precision Medicine, Binzhou Medical University, Yantai, P. R. China

*: These authors contribute equally

\#: To whom the correspondence should be addressed at jiandi.zhang@outlook.com.

Keywords: QDB, FFPE, cyclin D1, Ki67, Luminal-like, breast, prognosis 


\begin{abstract}
Purpose: Both Ki67 and cyclin D1 are routinely used protein biomarkers of cell proliferation for breast cancer patients. Ki67 is used to differentiate Luminal A-like from Luminal-B like subtype in surrogate assay. These two proliferative factors are investigated in this retrospective study to evaluate their prognostic role on the overall survival (OS) of Luminal-like breast cancer patients.
\end{abstract}

Method: The cyclin D1 protein level was measured absolutely and quantitatively using Quantitative Dot Blot (QDB) method in 143 Luminal-like FFPE breast cancer specimens. An optimized cutoff at $0.71 \mu \mathrm{mole} / \mathrm{g}$ was identified and used to separate these specimens into cyclin D1 high and low groups alone, or in combination with Ki67, for overall survival (OS) analyses of these patients.

Results: Cyclin D1 was found to be an independent prognostic factor from Ki67 in univariate and multivariate analysis. When both biomarkers were used to separate these Luminal-like specimens, the group with low expression of both biomarkers $(n=52)$ had significantly improved 10 year survival probability at $94 \%$, while the one with high expression of both markers $(n=34)$ were at $41 \%$ based on Kaplan-Meier survival analysis of OS (Log rank test $p<0.0001)$.

Conclusion: We demonstrated cyclin D1 as an independent prognostic protein biomarker from Ki67 for Luminal-like breast cancers. The combined usage of cyclin D1 and Ki67 significantly improved the prognosis over current prevailing surrogate assay. We propose to incorporate cyclin D1 in surrogate assay to improve prognosis for Luminal-like breast cancer patients in future clinical practice. 
medRxiv preprint doi: https://doi.org/10.1101/2020.04.15.20066993; this version posted April 20, 2020. The copyright holder for this preprint

(which was not certified by peer review) is the author/funder, who has granted medRxiv a license to display the preprint in perpetuity.

It is made available under a CC-BY-NC-ND 4.0 International license .

\section{Introduction}

The Luminal-like breast cancer, featured by overexpression of estrogen receptor $(E R)$, is defined in surrogate assay as tumors with $\geqslant 1 \%$ positive staining of ER with immunohistochemistry (IHC) in daily clinical practice[1-4]. This group of tumors are further separated into Luminal A-like and Luminal B-like subtypes based on a protein biomarker of cell proliferation, Ki67. More specifically, based on IHC and/or Fluorescence in situ hybridization (FISH) analyses, those tumors with Ki67<14\%, Progesterone receptor (PR) $>20 \%$, and Her2 negative (Her2-) are defined as Luminal Alike subtype with better prognosis. The rest of the Luminal-like tumors are classified as Luminal B-like subtype, including both $\mathrm{B}_{1}(\mathrm{ER}+$, Her2-, Ki67>14\% or $\mathrm{PR}<20 \%)$ and $\mathrm{B}_{2}$ $(\mathrm{ER}+$, Her2+) subgroups.

Cyclin D1 is another commonly used protein biomarker of cell proliferation in routine clinical practice. While the exact biological role of Ki67 remains unclear until now[5], cyclin D1 is known as the key regulator of cell cycle progression. Overexpression of cyclin D1 drives the cells from $\mathrm{G} 1$ to $\mathrm{S}$ phase in mitosis[6]. In this study, we set out to investigate if there were any prognostic differences between these two protein biomarkers of cellular proliferation. More importantly, if we can improve prognosis using both protein biomarkers simultaneously.

In a previous study, we measured Ki67 protein levels absolutely and quantitatively in 143 Luminal-like Formalin Fixed Paraffin Embedded (FFPE) specimens using our independently developed Quantitative Dot Blot (QDB) method[7]. When replacing Ki67 
medRxiv preprint doi: https://doi.org/10.1101/2020.04.15.20066993; this version posted April 20, 2020. The copyright holder for this preprint (which was not certified by peer review) is the author/funder, who has granted medRxiv a license to display the preprint in perpetuity. It is made available under a CC-BY-NC-ND 4.0 International license .

score from IHC analysis with our absolutely quantitated Ki67 levels, we found the prognosis of surrogate assay was improved significantly for OS of Luminal-like tumors[7].

Along this line of thinking, in this study, the cyclin D1 protein levels were also measured quantitatively and absolutely using QDB method in the same 143 Luminal-like FFPE specimens reported in the previous study, and we used these results to demonstrate that cyclin D1 was an independent prognostic factor from Ki67. The combined usage of these two protein biomarkers achieved significantly better prognosis than that of surrogate assay for Luminal-like tumors.

\section{Materials and Methods}

\section{Human subjects and human cell lines}

A total of 143 Formalin Fixed Paraffin Embedded (FFPE) breast cancer tissues in 2x15 $\mu \mathrm{m}$ slices treated between 2008 and 2013 at Yantai Affiliated Hospital of Binzhou Medical University (Yantai, P. R. China) were collected sequentially. All the samples were obtained in accordance with the Declaration of Helsinki and were approved by the Medical Ethics Committee of Yantai Affiliated Hospital of Binzhou Medical University (Approval \#: 20191127001), with an informed Consent Forms waiver for archived specimens.

MCF-7 cell line was purchased from the Cell Bank of Chinese Academy of Sciences (Shanghai, China) and cultured as provider's instruction. 
medRxiv preprint doi: https://doi.org/10.1101/2020.04.15.20066993; this version posted April 20, 2020. The copyright holder for this preprint

(which was not certified by peer review) is the author/funder, who has granted medRxiv a license to display the preprint in perpetuity.

It is made available under a CC-BY-NC-ND 4.0 International license .

\section{General reagents}

The general reagents for cell culture were purchased from Thermo Fisher Scientifics

(Waltham, MA, USA). The chemicals used for protein expression were purchased from

Takara Inc. (Dalian, China), and Nickel-His GraviTrap affinity column for protein purification was purchased from GE Healthcare. All the other chemicals were purchased from Sinopharm Chemicals (Beijing, P. R. China).

Rabbit anti-cyclin D1 monoclonal antibody (EP12) was purchased from ZSGB-BIO (Beijing, China). HRP labeled Donkey Anti-Rabbit IgG secondary antibody was purchased from Jackson Immunoresearch lab (Pike West Grove, PA, USA). Pierce BCA protein quantification kit was purchased from Thermo Fisher Scientific Inc.

(Calsband, CA, USA). Recombinant human cyclin D1 protein was prepared in the house. QDB plate was manufactured by Quanticision Diagnostics Inc at RTP, NC, USA.

\section{Preparation of recombinant cyclin D1 protein}

A DNA sequence corresponding to the 271-295AA of human cyclin D1 (NCBI \#: NP_444284.1) was inserted into PET32a (+) expression vector and verified by DNA sequencing. The plasmid was expressed in BL21 (DE3) competent cells after induction of IPTG. Total bacterial protein lysate was extracted in binding buffer $(20 \mathrm{mM}$ sodium phosphate, $500 \mathrm{mM} \mathrm{NaCl}, 20 \mathrm{mM}$ imidazole, $\mathrm{PH}$ 7.4) by ultrasonication. Recombinant cyclin D1 protein of bacterial lysate was purified by Ni-NTA column according to the instructions. Fractions containing cyclin D1 protein were pooled and concentrated on a 
medRxiv preprint doi: https://doi.org/10.1101/2020.04.15.20066993; this version posted April 20, 2020. The copyright holder for this preprint (which was not certified by peer review) is the author/funder, who has granted medRxiv a license to display the preprint in perpetuity. It is made available under a CC-BY-NC-ND 4.0 International license .

Milipore ultrafiltration spin column. Protein concentration of cyclin D1 was determined using BCA protein quantification kit, and the purity was determined by SDS-PAGE before aliquots were stored at $-80^{\circ} \mathrm{C}$.

\section{Preparation of FFPE tissues and cell lysates}

Breast cancer FFPE specimens in 2x15 $\mu \mathrm{m}$ slices were de-paraffinized and solubilized with lysis buffer (50 mM HEPES, 137 mM NaCl, 5 mM EDTA, 1 mM MgCl, 10 mM $\mathrm{Na}_{2} \mathrm{P}_{2} \mathrm{O}_{7}, 1 \%$ TritonX-100, 10\% glycerol). MCF-7 cell pellet was collected and Formalin-fixed for $30 \mathrm{~min}$ before solubilization with the same lysis buffer. The supernatants were collected after centrifugation for QDB analysis. Protein concentration was detected using BCA protein quantification kit.

\section{QDB analysis}

The QDB process was described previously with minor modifications[8-11]. In brief, FFPE tissue lysates (about $0.35 \mu \mathrm{g} / \mathrm{unit}$ ) and MCF-7 cell lysate (about $0.08 \mu \mathrm{g} / \mathrm{unit}$ ) were applied onto the QDB plate at $2 \mu \mathrm{l} /$ unit in triplicate. Serially diluted cyclin D1 recombinant protein was included in each plate as protein standard for calculation of the absolute cyclin D1 protein levels. The loaded QDB plate was dried in the air for $4 \mathrm{~h}$ and then blocked with blocking buffer ( $4 \%$ non-fat milk in TBST) for $1 \mathrm{~h}$. The plate was inserted into 96-well microplate pre-filled with $100 \mu \mathrm{l}$ anti-cyclin D1 antibody (clone EP12, 1:500 in blocking buffer) and incubated overnight at $4^{\circ} \mathrm{C}$. The plate was rinsed twice and washed 4X10 mins before it was incubated with a donkey anti-rabbit secondary antibody for another 4 hours at room temperature. The plate was then 
medRxiv preprint doi: https://doi.org/10.1101/2020.04.15.20066993; this version posted April 20, 2020. The copyright holder for this preprint (which was not certified by peer review) is the author/funder, who has granted medRxiv a license to display the preprint in perpetuity. It is made available under a CC-BY-NC-ND 4.0 International license .

rinsed twice and washed 5X10 mins before being processed with ECL reagent and quantified with a Tecan Microplate reader. The chemiluminescence signals were converted into absolute cyclin D1 protein level in each sample using protein standard. All results were averages of three independent experiments, with each sample in triplicate.

MCF-7 cell lysate was used as internal control. The absolute cyclin D1 level of MCF-7 cell lysate was measured with QDB method and the results were documented. The overall experiment was judged as valid when the measured cyclin D1 level of MCF-7 cell lysate fell within $\pm 20 \%$ of the documented value.

\section{Statistical analysis}

All the statistical analyses were done using either R version 3.6.2 (http://www.rproject.org) or GraphPad Prism 7 (La Jolla, CA, USA). The results were reported as mean \pm standard error of the mean $($ SEM). A p-value of $<0.05$ was defined as statistically significant. The correlation between cyclin D1 and Ki67 protein levels was analyzed with Spearman's correlation coefficient analysis. Differences in the clinicopathologic features between patients assigned to $\mathrm{C}_{\mathrm{I}} \mathrm{K}_{\mathrm{l}}$ and $\mathrm{C}_{\mathrm{h}} \mathrm{K}_{\mathrm{h}}$ groups were examined using Chi-squared test.

The endpoint of overall survival analysis was defined as the time from breast surgery to death or last follow-up (April 1st, 2019). Survival data for patients who were still alive at the date of last follow-up were treated as censored. Cyclin D1 levels measured by QDB 
medRxiv preprint doi: https://doi.org/10.1101/2020.04.15.20066993; this version posted April 20, 2020. The copyright holder for this preprint

(which was not certified by peer review) is the author/funder, who has granted medRxiv a license to display the preprint in perpetuity.

It is made available under a CC-BY-NC-ND 4.0 International license .

method were dichotomized for OS analysis, using optimized cutoff value determined by the "surv_cutpoint" function of the "surviminer" R package. A total of 143 Luminal-like patients in surrogate assay were grouped into low cyclin D1 group and high cyclin D1 group.

The relationship between Ki67 and/or cyclin D1 and OS of Luminal-like specimens was evaluated using the log-rank test and visualized by Kaplan-Meier survival curve analysis. Univariate Cox proportional hazard model fitted overall survival was employed for hazard ratio (HR) and corresponding 95\% confidence intervals (Cls) estimation. Multivariable Cox model was used to examine the association between Ki67 and/or cyclin D1 and OS with adjusting for clinical factors, such as age, node status, tumor size, tumor grade, and type of treatment. The Schoenfeld residuals test is used to test the proportional Hazard assumption in Cox Model.

\section{Results}

The clinicopathological characteristics of all 143 Luminal-like FFPE specimens were described in Table. 1. These specimens were collected sequentially from local hospital, as described in the Materials and Methods section.

Total protein lysates were extracted from 2X15 $\mu \mathrm{m}$ FFPE tissue slices from each individual specimen. The linear ranges of both total tissue lysates and recombinant cyclin D1 protein were defined using QDB method (Supplemental Fig. 1). As shown in Fig. 1a, the distribution of cyclin D1 levels were from 0.01 to $5.63 \mu$ mole/g, with mean at $0.83 \pm 0.07 \mu \mathrm{mole} / \mathrm{g}$. The expression levels of cyclin D1 were weakly correlated with 
medRxiv preprint doi: https://doi.org/10.1101/2020.04.15.20066993; this version posted April 20, 2020. The copyright holder for this preprint (which was not certified by peer review) is the author/funder, who has granted medRxiv a license to display the preprint in perpetuity. It is made available under a CC-BY-NC-ND 4.0 International license .

those of Ki67 when analyzed using Spearman's correlation analysis $(\rho=0.29, p=0.0005$, $n=143)$.

The putative prognostic role of cyclin D1, alongside with Ki67, for OS of Luminal-like breast tumors was explored first with univariate survival analysis (Table. 2). Both cyclin D1 and Ki67 were found to be independent prognostic factor for the OS of the patients, with HR for Ki67 at 1.18 (95\% Cl: 1.05-1.31, p=0.0035) and for cyclin D1 at 1.47 (95\% $\mathrm{Cl}: 1.12-1.93, \mathrm{p}=0.0056)$ respectively. In addition, other factors including node status and age were also found to be statistically significant, while the tumor size, treatment and tumor grade were found not to be significantly associated with OS of the patients.

The prognostic roles of both cyclin D1 and Ki67 for OS were next analyzed with multivariate cox regression survival analysis. Unexpectedly, although both factors are biomarkers of cell proliferation, they were found to be independent prognostic factor from each other, with $\mathrm{HR}$ for Ki67 at 1.19 (95\% Cl: 1.04-1.37, $\mathrm{p}=0.0138)$ and for cyclin D1 at 1.45 (95\% Cl: 1.04-2.02, $p=0.0291)$. Again, the age and node status were found to be independent prognostic factor in the same analysis.

The fact that cyclin D1 and Ki67 were independent prognostic factors from each other prompted us to investigate if we can improve the prognosis of Luminal-like tumors using both factors. Therefore, we tried first to identify the optimized cyclin D1 cutoff value to separate Luminal-like specimens for OS analysis. This value was determined by the "surv_cutpoint" function of the "surviminer" R package at $0.71 \mu \mathrm{mole} / \mathrm{g}$ and used to 
medRxiv preprint doi: https://doi.org/10.1101/2020.04.15.20066993; this version posted April 20, 2020. The copyright holder for this preprint (which was not certified by peer review) is the author/funder, who has granted medRxiv a license to display the preprint in perpetuity. It is made available under a CC-BY-NC-ND 4.0 International license .

separate these Luminal-like specimens into cyclin D1 high $\left(C_{h}\right)$ and low $\left(C_{l}\right)$ groups. The OS analysis of the resulted $\mathrm{C}_{\mathrm{h}}$ and $\mathrm{C}_{\mathrm{I}}$ group was done using Kaplan-Meier survival analysis (Fig. 2). We found $\mathrm{C}$, group have 10 -year survival probability at $89 \%$, in comparison to the $57 \%$ for $\mathrm{C}_{\mathrm{h}}$ group, with $\mathrm{p}<0.0001$ from Log Rank test. As an comparison, the prognosis from adjusted surrogate assay, where the Luminal-like specimens were subtyped based on absolutely quantitated Ki67 protein levels, had the 10-year survival probability at $91 \%$ for Luminal A-like subtype, and $63 \%$ for Luminal Blike subtype, with $p=0.00052[7]$. For current prevailing surrogate assay, the 10 -year survival probability was at $88 \%$ for Luminal A-like subtype, and $68 \%$ for Luminal B-like subtype with $p=0.031$ from Log Rank test using the same specimens.

These Luminal-like specimens were also separated into Ki67 high ( $\left.\mathrm{K}_{\mathrm{h}}\right)$ and Ki67 low (K⿺) group using the $2.31 \mathrm{nmole} / \mathrm{g}$ we defined in the previous study[7]. These two cutoffs were used together to further separate the Luminal-like specimens into four groups, with $\mathrm{C}_{h} \mathrm{~K}_{\mathrm{h}}$ for specimens with the expression levels of both biomarkers above the respective cutoffs, $\mathrm{Cl}_{\mathrm{I}} \mathrm{K}$ for those below the respective cutoffs. $\mathrm{C}_{\mathrm{h}} \mathrm{K}_{\mathrm{I}}$ refers to specimens with only cyclin D1 level above the corresponding cutoff, while the $\mathrm{C}_{1} \mathrm{~K}_{\mathrm{h}}$ refers to those with only Ki67 level above the corresponding cutoff. The OS of these four groups were analyzed using Kaplan-Meier survival analysis in Fig. 3. We found the $C_{1} K_{ı}$ group $(n=52)$ had significantly improved 10-year survival probability at 94\% (95\% Cl: 0.86-1), while $\mathrm{ChK}_{\mathrm{h}}$ group $(n=34)$ had the worst 10 -year survival probability at $41 \%(95 \% \mathrm{Cl}: 0.24-0.69)$. The $\mathrm{C}_{h} \mathrm{~K}_{\mathrm{I}}(\mathrm{n}=22)$ and $\mathrm{C}_{\mathrm{I}} \mathrm{K}_{\mathrm{h}}(\mathrm{n}=35)$ group had similar 10 -year survival probability at $77 \%$ (95\% Cl: 0.61-0.97) and 83\% (95\% Cl: 0.71-0.96) respectively. The p value from Log 
medRxiv preprint doi: https://doi.org/10.1101/2020.04.15.20066993; this version posted April 20, 2020. The copyright holder for this preprint

rank test was $<0.0001$. It should be emphasized that in this simple categorization, the potential impact of $\mathrm{PR}$ is not considered. In fact, the two deaths in $\mathrm{C}_{\mathrm{K}} \mathrm{K}$ group were all found to be associated with low PR expression (unpublished data).

The clinicopathological parameters from both $\mathrm{C}_{\mathbb{1}} \mathrm{K}_{\mathrm{I}}$ group with the best prognosis, and $\mathrm{C}_{\mathrm{h}} \mathrm{K}_{\mathrm{h}}$ group with the worst prognosis, were also compared in Supplemental table. 1. We found that these two groups were similar at age, treatment, and node status.

Consistent with the prior knowledge, there were more patients with T1 stage in tumor size, and grade II in histological grade in $\mathrm{C}_{\mid} \mathrm{K}_{\mathrm{I}}$ group than those of $\mathrm{C}_{h} \mathrm{~K}_{h}$ group. Yet, none of them reached statistically significance due to the small sample size.

\section{Discussion}

In this study, the cyclin D1 levels were absolutely and quantitatively measured using QDB method in 143 Luminal-like FFPE specimens. We found that cyclin D1 was an independent prognostic factor from Ki67 for OS of Luminal-like patients. More importantly, we found the combined use of Ki67 and cyclin D1 significantly improved the prognosis of OS of Luminal-like breast cancer.

As shown in table 4, when both biomarkers were used, we identified $\mathrm{C}_{\mathrm{I}} \mathrm{K}_{\mathrm{I}}$ group with the best prognosis $(n=52)$, with 10-year survival probability at $94 \%$, in comparison to the Luminal A-like subtype at $91 \%$ for adjusted surrogate assay $(n=69)$, and $88 \%$ for surrogate assay $(n=61)$; and $C_{h} K_{h}$ group with the worst prognosis $(n=34)$ with 10-year survival probability at $41 \%$, in comparison to $63 \%$ for Luminal B-like subtype from 
medRxiv preprint doi: https://doi.org/10.1101/2020.04.15.20066993; this version posted April 20, 2020. The copyright holder for this preprint

adjusted surrogate assay $(n=74)$ and $68 \%$ from surrogate assay $(n=82)[7]$. In addition, in $\mathrm{ChK}_{h}$ group, the percentage of deceased patients were $47.05 \%(16 / 34)$, in comparison to $31.08 \%(23 / 74)$ in Luminal B-like subtype from adjusted surrogate assay and $26.83 \%$ (22/82) from surrogate assay.

Although there are extensive studies about the prognostic role of cyclin D1 among breast cancer patients, the conclusion remains controversial, even among patients of ER+. All these results were well summarized in Ahlin et al and several other studies[6, $12,13]$. We suspect these studies were seriously limited by the method used in these studies. For example, IHC is used primary for assessment of cyclin D1 protein levels in breast cancer specimens[6]. Yet, this method is known to be associated with inconsistency and subjectivity[14]. By using QDB method in this study, these issues were well circumvented, and we were able to show a strong correlation of overexpression of cyclin D1 with reduced survival of ER+ patients, supported by both the univariate and multivariate cox regression survival analyses.

More importantly, we demonstrated for the first time that cyclin D1 is an independent prognostic biomarker from Ki67. Thus, the combined use of these two biomarkers in daily clinical practice should significantly improve the prognosis of Luminal-like patients. Although the role of cyclin D1 in basal-like tumors remains to be explored, considering that around $60 \sim 70 \%$ tumors are Luminal-like tumors[3], cyclin D1 is highly recommended to be included in the routine subtyping practice for breast cancer patients. 
medRxiv preprint doi: https://doi.org/10.1101/2020.04.15.20066993; this version posted April 20, 2020. The copyright holder for this preprint

In this study, we also separate all the Luminal-like specimens into four groups of $\mathrm{C}_{\mathrm{h}} \mathrm{K}_{\mathrm{h}}$,

$\mathrm{C}_{h} \mathrm{~K}_{\mathrm{l}}, \mathrm{C}_{\mathrm{I}} \mathrm{K}_{\mathrm{h}}$ and $\mathrm{C}_{\mathrm{I}} \mathrm{K}_{\mathrm{I}}$ simply using our proposed cutoffs at $0.71 \mu \mathrm{mole} / \mathrm{g}$ for cyclin $\mathrm{D} 1$ and $2.31 \mathrm{nmole} / \mathrm{g}$ for Ki67, without considering the potential impact of PR and Her2 in the analysis. Even under this crude classification, we still provided a better prognosis than that from the current available surrogate assay.

It should be emphasized that this study is by no means to dismiss the prognostic role of PR. Rather, this factor is yet to be incorporated in current prognostic method. In fact, consistent with the protective role of PR in surrogate assay, the only two deaths in the $\mathrm{C}_{\mathrm{K}} \mathrm{I}$ group in our study are with low expression of PR (unpublished data). Clearly, with more specimens available, a better algorithm will be developed to incorporate PR, cyclin D1 and Ki67 in the prognosis evaluation of Luminal-like patients.

It should also be pointed out that this is only a preliminary study, with merely 143 Luminal-like FFPE specimens available for analysis. The analysis was also only limited to the OS of these patients. More retrospective and prospective studies are urgently needed to verify our conclusion, so that patients worldwide can benefit from this finding sooner. The prognostic effect of cyclin D1 on the Disease-free survival (DFS) should also be investigated in the future.

In conclusion, by measuring cyclin D1 protein levels absolutely and quantitatively in 143 Luminal-like FFPE specimens, we demonstrated that overexpression of cyclin D1 was 
negatively associated with the survival of Luminal-like patients, and the combined usage of cyclin D1 and Ki67 significantly improve the prognosis of Luminal-like patients. We proposed to use cyclin D1 together with Ki67 protein biomarkers routinely in daily clinical practice to aid subtyping of breast cancer patients.

\section{Acknowledgements}

\section{Author contributions}

JH, JZou, SX \& CZ provided clinical samples \& JH supervised all the clinical studies; WZ, YL, YZ, JL, \& FT performed all the assays and data analysis; FT supervised all the assays; YL performed all the statistical analysis, JZhang designed \& supervised the overall study and drafted the manuscript; WZ, JZhang \& FT contributed to data interpretation and edited the manuscript.

Conflicting of interest: WZ, YL, YZ, JL, JZhang \& FT are employees of Yantai Quanticision Diagnostics, Inc., a division of Quanticision Diagnostics, Inc., who own or has filed patent applications for QDB plate, QDB method, \& QDB application in clinical diagnostics.

JH, JZou, SX \& CZ declared no conflict of interest.

\section{Funding}

This study was funded by Yantai Quanticision Diagnostics, Inc. \& Binzhou Medical University Fund 
medRxiv preprint doi: https://doi.org/10.1101/2020.04.15.20066993; this version posted April 20, 2020. The copyright holder for this preprint

(which was not certified by peer review) is the author/funder, who has granted medRxiv a license to display the preprint in perpetuity. It is made available under a CC-BY-NC-ND 4.0 International license .

\section{References}

1. Perou CM, Sørlie T, Eisen MB et al. Molecular portraits of human breast tumours. Nature 2000; 406(6797):747-752.

2. Goldhirsch A, Winer EP, Coates AS et al. Personalizing the treatment of women with early breast cancer: highlights of the St Gallen International Expert Consensus on the Primary Therapy of Early Breast Cancer 2013. Ann Oncol 2013; 24(9):2206-2223.

3. Yersal O, Barutca S. Biological subtypes of breast cancer: Prognostic and therapeutic implications. World J Clin Oncol 2014; 5(3):412-424.

4. Sørlie T, Perou CM, Tibshirani R et al. Gene expression patterns of breast carcinomas distinguish tumor subclasses with clinical implications. Proc. Natl. Acad. Sci. U.S.A. 2001; 98(19):10869-10874.

5. Juríková M, Danihel L', Polák Š, Varga I. Ki67, PCNA, and MCM proteins: Markers of proliferation in the diagnosis of breast cancer. Acta Histochemica 2016; 118(5):544-552.

6. Ahlin C, Lundgren C, Embretsén-Varro E et al. High expression of cyclin D1 is associated to high proliferation rate and increased risk of mortality in women with ERpositive but not in ER-negative breast cancers. Breast Cancer Res Treat 2017; 164(3):667-678.

7. Hao J, Lv Y, Zou J et al. Improving prognosis of surrogate assay for breast cancer patients by absolute quantitation of Ki67 protein levels using Quantitative Dot Blot (QDB) method. medRxiv 2020:2020.03.11.20034439.

8. Tian G, Tang F, Yang C et al. Quantitative dot blot analysis (QDB), a versatile high throughput immunoblot method. Oncotarget 2017; 8(35):58553-58562.

9. Zhang W, Yu G, Zhang Y et al. Quantitative Dot Blot (QDB) as a universal platform for absolute quantification of tissue biomarkers. Analytical Biochemistry 2019; 576:42-47.

10. Yu G, Zhang W, Zhang Y et al. Developing a routine lab test for absolute quantification of Her2 in Formalin Fixed Paraffin Embedded (FFPE) breast cancer tissues using Quantitative Dot Blot (QDB) method. bioRxiv 2019:584615.

11. Qi X, Zhang Y, Zhang Y et al. High Throughput, Absolute Determination of the Content of a Selected Protein at Tissue Levels Using Quantitative Dot Blot Analysis (QDB). JoVE (Journal of Visualized Experiments) 2018; (138):e56885-e56885.

12. Lundberg A, Lindström LS, Harrell JC et al. Gene Expression Signatures and Immunohistochemical Subtypes Add Prognostic Value to Each Other in Breast Cancer Cohorts. Clin Cancer Res 2017; 23(24):7512-7520. 
medRxiv preprint doi: https://doi.org/10.1101/2020.04.15.20066993; this version posted April 20, 2020. The copyright holder for this preprint (which was not certified by peer review) is the author/funder, who has granted medRxiv a license to display the preprint in perpetuity. It is made available under a CC-BY-NC-ND 4.0 International license .

13. Lundberg A, Lindström LS, Li J et al. The long-term prognostic and predictive capacity of cyclin D1 gene amplification in 2305 breast tumours. Breast Cancer Res. 2019; 21(1):34.

14. Gown AM. Diagnostic Immunohistochemistry: What Can Go Wrong and How to Prevent It. Archives of Pathology \& Laboratory Medicine 2016; 140(9):893-898. 
medRxiv preprint doi: https://doi.org/10.1101/2020.04.15.20066993; this version posted April 20, 2020. The copyright holder for this preprint (which was not certified by peer review) is the author/funder, who has granted medRxiv a license to display the preprint in perpetuity. It is made available under a CC-BY-NC-ND 4.0 International license .

Figure legends

Figure 1. The cyclin D1 protein levels in 143 Luminal-like breast cancer FFPE tissues. A total of 143 Luminal-like breast cancer FFPE tissues in $2 \times 15 \mu \mathrm{m}$ slices were collected sequentially from local hospital, and the total protein lysates were prepared as described in Materials and Methods. MCF-7 cell lysate was used as internal control. FFPE tissue lysates (about $0.35 \mu \mathrm{g} / \mathrm{unit}$ ) and cell lysate (about $0.08 \mu \mathrm{g} / \mathrm{unit}$ ) were applied onto the QDB plate at $2 \mu \mathrm{l} / \mathrm{unit}$ in triplicate for QDB analysis using anti-cyclin D1 antibody. Serially diluted cyclin D1 recombinant protein were included in each plate as protein standard. All results were averages of three independent experiments, with each sample in triplicate. (a) cyclin D1 levels were from 0.01 to $5.63 \mu \mathrm{mole} / \mathrm{g}$, with mean at $0.83 \mu \mathrm{mole} / \mathrm{g}$ and median at $0.58 \mu \mathrm{mole} / \mathrm{g}$. (b) The correlation between cyclin D1 and Ki67 protein levels in 143 FFPE tissues was analyzed with Spearman's correlation coefficient analysis using Graphpad software, $\rho=0.29, p=0.0005$.

Figure 2. Kaplan-Meier curves for overall survival (OS) of Luminal-like specimens divided into cyclin D1 low $\left(C_{l}\right)$ and high groups $\left(C_{h}\right)$ by the protein levels of Cyclin D1, using $0.71 \mu$ mole/g as cutoff. Optimal cutoff value of cyclin D1 level was determined at $0.71 \mu \mathrm{mole} / \mathrm{g}$ by the "surv_cutpoint" function of the "surviminer" $\mathrm{R}$ package. The 5-year and 10-year survival probabilities, and the $p$ values from Log Rank test were provided in the figure. $\mathrm{Cl}$, confidence interval; $p$, log-rank $p$-value.

Figure 3. Kaplan-Meier curves for overall survival (OS) of Luminal-like specimens grouped by both the Ki67 and Cyclin D1 protein levels. The specimens were 
medRxiv preprint doi: https://doi.org/10.1101/2020.04.15.20066993; this version posted April 20, 2020. The copyright holder for this preprint (which was not certified by peer review) is the author/funder, who has granted medRxiv a license to display the preprint in perpetuity. It is made available under a CC-BY-NC-ND 4.0 International license .

separated into four groups using Cyclin D1 at $0.71 \mu \mathrm{mole} / \mathrm{g}$ and Ki67 at $2.31 \mathrm{nmole} / \mathrm{g}$ as cutoffs respectively. $\mathrm{C}_{\mathrm{I}} \mathrm{K}_{\mathrm{I}}$ stands for specimens with the protein levels of both biomarkers below the respective cutoffs, $\mathrm{C}_{\mathrm{l}} \mathrm{K}$ for those with only Cyclin $\mathrm{D} 1$ level below the recommended cutoff, $\mathrm{ChK}_{\mathrm{h}}$ for those with only Ki67 levels below the recommended cutoff, and $\mathrm{C}_{h} \mathrm{~K}_{\mathrm{h}}$ for those with both biomarkers above the respective cutoffs. The 5year and 10-year survival probabilities, and the $p$ values from Log Rank test were provided in the figure. 
medRxiv preprint doi: https://doi.org/10.1101/2020.04.15.20066993; this version posted April 20, 2020. The copyright holder for this preprint (which was not certified by peer review) is the author/funder, who has granted medRxiv a license to display the preprint in perpetuity. It is made available under a CC-BY-NC-ND 4.0 International license .

Fig 1.

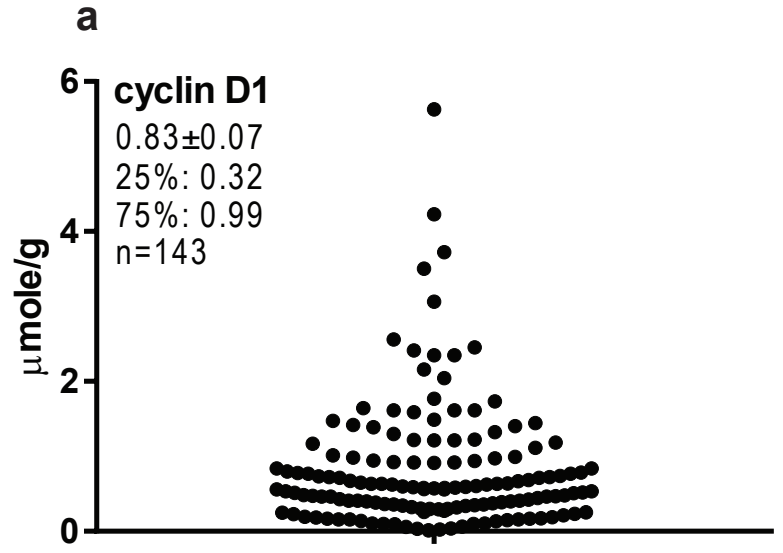

b

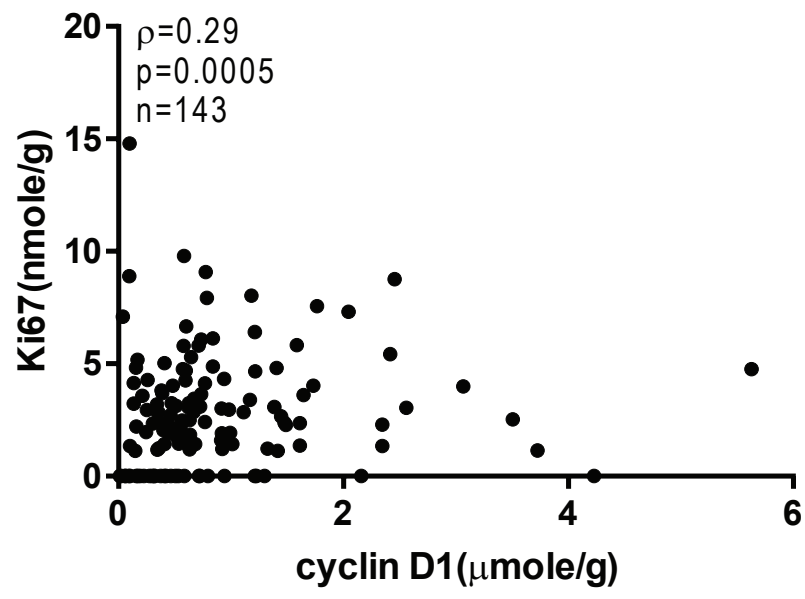


Finedgxiv preprint doi: https://doi.org/10.1101/2020.04.15.20066993; this version posted April 20, 2020. The copyright holder for this preprint fwhich was not certified by peer review) is the author/funder, who has granted medRxiv a license to display the preprint in perpetuity. It is made available under a CC-BY-NC-ND 4.0 International license

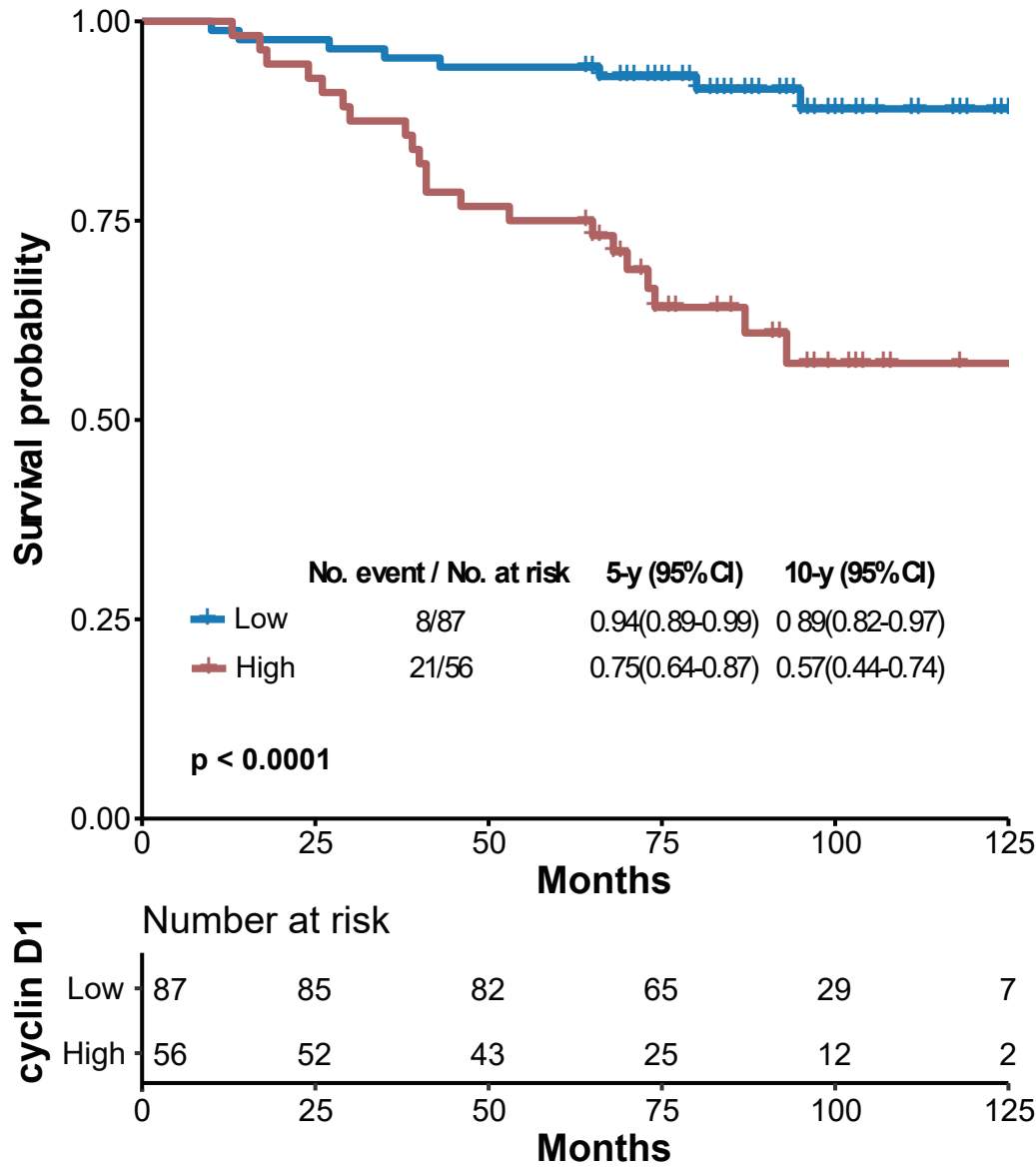


Fig 3

(hiv preprint doi: https://doi.org/10.1101/2020.04.15.20066993; this version posted April 20, 2020. The copyright holder for this preprint (which was not certified by peer review) is the author/funder, who has granted medRxiv a license to display the preprint in perpetuity. It is made available under a CC-BY-NC-ND 4.0 International license .

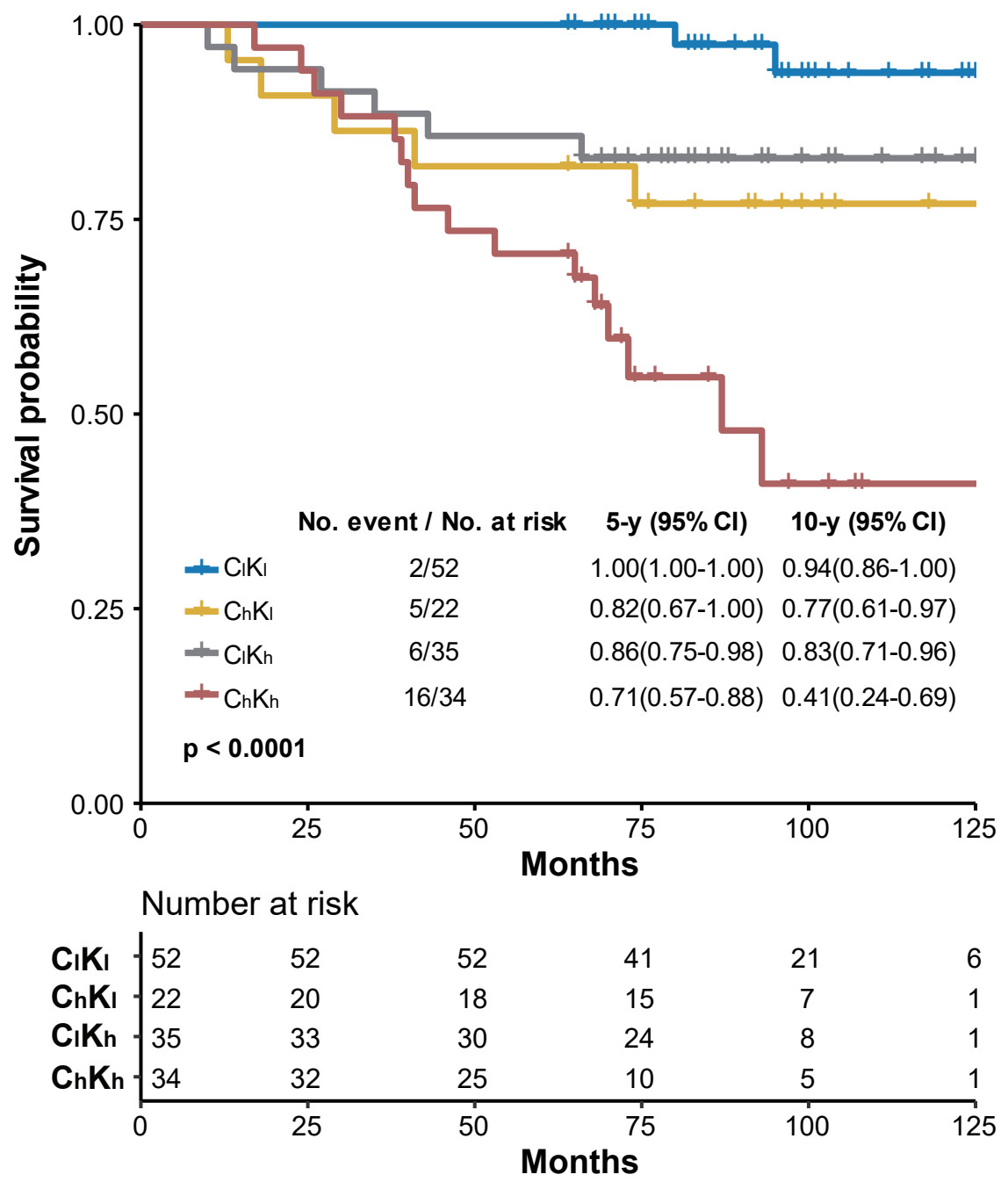


Table 1. Clinicopathological Characteristics of 143 Luminal-like specimens

\begin{tabular}{ll}
\hline Characteristics & Number of Cases (\%) \\
\hline Age & \\
$<50$ & $63(44.06)$ \\
$\geq 50$ & $80(55.94)$ \\
Treatment & \\
Endo & $2(1.4)$ \\
Chemo & $85(59.44)$ \\
Endo\&Chemo & $36(25.17)$ \\
Unknown & $20(13.99)$ \\
Node Status & \\
N0 & $65(45.45)$ \\
N1 & $56(39.16)$ \\
N2 & $9(6.29)$ \\
N3 & $7(4.9)$ \\
Unknown & $6(4.2)$ \\
Tumor Size & \\
T1 & $50(34.97)$ \\
T2 & $83(58.04)$ \\
T3 & $7(4.9)$ \\
Unknown & $3(2.1)$ \\
Grade & \\
II & $77(53.85)$ \\
III & $47(32.87)$ \\
Unknown & $19(13.29)$ \\
\hline
\end{tabular}




$\begin{aligned} & \text { Table 2. Univariate Cox regression analysis of } \\
& \text { Overall Survival (OS) of Ki67 and cyclin D1 } \\
& \text { protein levels }\end{aligned}$
\begin{tabular}{lccc}
\hline Variable & HR & $\mathbf{9 5 \%}$ Cl & P-value \\
\hline age & 3.24 & $1.32-7.96$ & 0.0103 \\
treatment & 1.10 & $0.67-1.78$ & 0.7127 \\
LNs & 1.68 & $1.29-2.19$ & 0.0001 \\
tumor size & 1.42 & $0.83-2.42$ & 0.2031 \\
grade & 1.10 & $0.67-1.83$ & 0.7008 \\
Ki67 & 1.18 & $1.05-1.31$ & 0.0035 \\
cyclin D1 & 1.47 & $1.12-1.93$ & 0.0056 \\
\hline
\end{tabular}

Both Ki67 and cyclin D1 levels of these 143 Luminal-like specimens were measured by QDB method as continuous variables and used for univariate cox regression analysis for OS. 


Table 3. Multivariate Cox regression analysis of Overall
Survival (OS) of Ki67 and cyclin D1 protein levels
adjusted for clinical variables
\begin{tabular}{lccc}
\hline Variable & HR & $\mathbf{9 5 \%}$ Cl & P-value \\
\hline Age & 4.11 & $1.61-10.47$ & 0.0030 \\
Treatment & 0.90 & $0.54-1.51$ & 0.7030 \\
Node Status & 1.72 & $1.26-2.34$ & 0.0007 \\
Tumor Size & 1.35 & $0.67-2.75$ & 0.4028 \\
Grade & 0.87 & $0.45-1.68$ & 0.6825 \\
Ki67 & 1.19 & $1.04-1.37$ & 0.0138 \\
cyclin D1 & 1.45 & $1.04-2.02$ & 0.0291 \\
\hline
\end{tabular}

Multivariate survival analysis was performed using the Cox proportional hazards model adjusted for age, treatment, node status, tumor size and tumor grade. 
Table 4. Performance of three subtyping methods

\begin{tabular}{lccc}
\hline Methods & No. event / No. at risk & 10-y OS probability(95\% Cl) & p-value \\
\hline cyclin D1\&Ki67 method & & & $<0.0001$ \\
$\mathrm{C}_{\|} \mathrm{K}_{\mathrm{I}}$ & $2 / 52(3.85 \%)$ & $94 \%(86 \%-100 \%)$ & \\
$\mathrm{C}_{\mathrm{h}} \mathrm{K}_{\mathrm{I}}$ & $5 / 22(22.73 \%)$ & $77 \%(61 \%-97 \%)$ & \\
$\mathrm{C}_{\mid} \mathrm{K}_{\mathrm{h}}$ & $6 / 35(17.14 \%)$ & $83 \%(71 \%-96 \%)$ & \\
$\mathrm{C}_{\mathrm{h}} \mathrm{K}_{\mathrm{h}}$ & $16 / 34(47.96 \%)$ & $41 \%(24 \%-69 \%)$ & \\
Adjusted surrogate assay & & & \\
$\quad$ Luminal $\mathrm{A}_{\mathrm{q}}$ & $6 / 69(8.70 \%)$ & $91 \%(84 \%-98 \%)$ & \\
$\quad$ Luminal $\mathrm{B}_{\mathrm{q}}$ & $23 / 74(31.08 \%)$ & $63 \%(50 \%-78 \%)$ & \\
Surrogate assay & & & \\
$\quad$ Luminal $\mathrm{A}_{\mathrm{i}}$ & $7 / 61(11.48 \%)$ & $88 \%(80 \%-97 \%)$ & \\
$\quad$ Luminal $\mathrm{B}_{\mathrm{i}}$ & $22 / 82(26.83 \%)$ & $68 \%(58 \%-81 \%)$ & \\
\hline
\end{tabular}

$\mathrm{C}_{\mathrm{I}} \mathrm{K}_{\mathrm{l}}$ : specimens with both cyclin $\mathrm{D} 1$ and $\mathrm{Ki} 67$ levels below the respective suggested cutoffs; $\mathrm{C}_{\mathrm{h}} \mathrm{K}_{\mathrm{l}}$ : specimens with only Ki67 levels below the suggested cutoff; $\mathrm{C}_{\mid} \mathrm{K}_{\mathrm{h}}$ : specimens with only cyclin $\mathrm{D} 1$ below the suggested cutoff; $\mathrm{C}_{\mathrm{h}} \mathrm{K}_{\mathrm{h}}$ : specimens with both cyclin D1 and Ki67 levels above the respective suggested cutoffs; Luminal $A_{q}$ \& Luminal $B_{q}$ : Luminal A-like and B-like subtypes based on absolute quantitated Ki67 levels using QDB method, using $2.31 \mathrm{nmole} / \mathrm{g}$ as cutoff[7]; Luminal $\mathrm{A}_{\mathrm{i}} \& \mathrm{~B}_{\mathrm{i}}$ : Luminal A-like and B-like subtypes based on Ki67 scores from IHC analysis, using $14 \%$ as cutoff[7]. 
medRxiv preprint doi: https://doi.org/10.1101/2020.04.15.20066993; this version posted April 20, 2020. The copyright holder for this preprint (which was not certified by peer review) is the author/funder, who has granted medRxiv a license to display the preprint in perpetuity. It is made available under a CC-BY-NC-ND 4.0 International license.

\section{Supplemental Fig 1.}

a

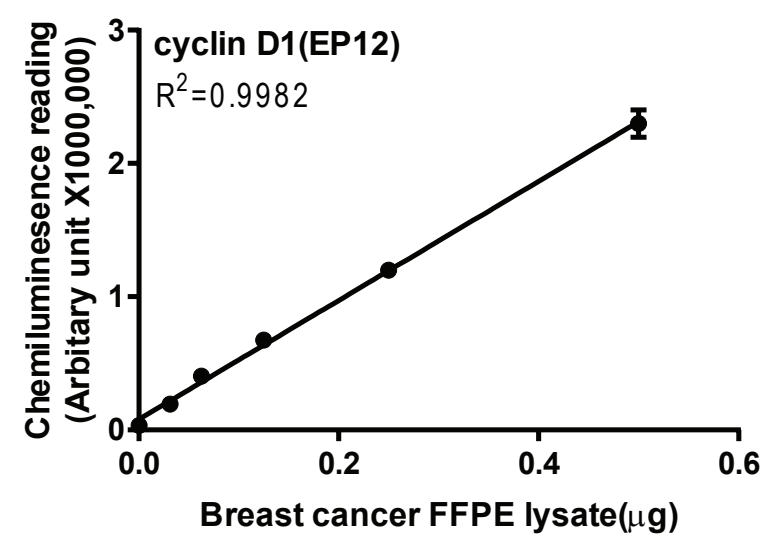

b

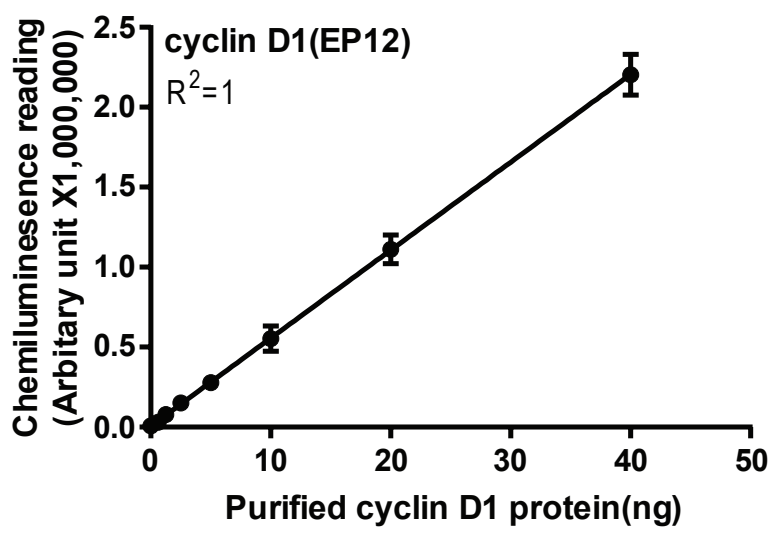


Supplemental fig 1. Defining the linear ranges of QDB analysis. (a) Defining the linear range of QDB method with breast cancer FFPE lysate. Human breast cancer FFPE specimens in $2 \times 15 \mu \mathrm{m}$ slices were provided sequentially by local hospital, and the pooled FFPE lysate was prepared by mixing in equal amount of 4 total tissue lysates with high IHC scores for cyclin D1. The pooled lysate was serially diluted as indicated in the figure and supplemented with IgG-Free BSA solution to allow for equal loading (about $0.5 \mu \mathrm{g} / \mathrm{unit}$ ). The lysate was applied onto QDB plate at $2 \mu \mathrm{l} / \mathrm{unit}$ for QDB analysis using anti-cyclin D1 antibody (clone EP12). (b) Defining the linear range of QDB method with purified cyclin D1 protein. The cyclin D1 recombinant protein was serially diluted as indicated in the figure and supplemented with IgG-Free BSA solution. The diluted recombinant protein lysate was applied onto the QDB plate at $2 \mu / / u n i t$ for QDB analysis using anti-cyclin D1 antibody (clone EP12). 
Supplemental table 1. Clinicopathological characteristics of specimens in $C_{I} K_{I}$ and $C_{h} K_{h}$ groups

\begin{tabular}{|c|c|c|c|}
\hline \multirow[t]{2}{*}{ Characteristics } & \multicolumn{2}{|c|}{ Number of Cases(\%) } & \multirow[t]{2}{*}{$p$ value } \\
\hline & $C_{l} K_{l}$ Group(n=52) & $\mathrm{C}_{\mathrm{h}} \mathrm{K}_{\mathrm{h}} \operatorname{Group}(\mathrm{n}=34)$ & \\
\hline Age & & & 0.4262 \\
\hline$<50$ & 18(34.62) & $9(26.47)$ & \\
\hline$\geq 50$ & $34(65.38)$ & $25(73.53)$ & \\
\hline Treatment & & & 0.1766 \\
\hline Endo & 0 & $1(2.94)$ & \\
\hline Chemo & $37(71.15)$ & $20(58.82)$ & \\
\hline Endo\&Chemo & $13(25)$ & $8(23.53)$ & \\
\hline Unknown & $2(3.85)$ & $5(14.71)$ & \\
\hline Node Status & & & 0.606 \\
\hline NO & $29(55.77)$ & 14(41.18) & \\
\hline N1 & $16(30.77)$ & 14(41.18) & \\
\hline N2 & $3(5.77)$ & $3(8.82)$ & \\
\hline N3 & $3(5.77)$ & $3(8.82)$ & \\
\hline Unknown & $1(1.92)$ & 0 & \\
\hline Tumor Size & & & 0.2976 \\
\hline $\mathrm{T} 1$ & $21(40.38)$ & $9(26.47)$ & \\
\hline $\mathrm{T} 2$ & $28(53.85)$ & $23(67.65)$ & \\
\hline T3 & $3(5.77)$ & $1(2.94)$ & \\
\hline Unknown & 0 & $1(2.94)$ & \\
\hline Grade & & & 0.261 \\
\hline II & $33(63.46)$ & $16(47.06)$ & \\
\hline III & $13(25)$ & 14(41.18) & \\
\hline Unknown & $6(11.54)$ & $4(11.76)$ & \\
\hline
\end{tabular}

